\title{
Sınıf Öğretmenlerinin Çevreye Yönelik Bilgi, Tutum ve Davranış Düzeylerinin Íncelenmesi ${ }^{1}$
}

\author{
DOI: $10.26466 /$ opus.619973 \\ * \\ Ömer Erbasan $^{*}-$ Mehmet Erkol $^{* *}$ \\ * Öğretmen, Milli Eğitim Bakanlı̆̆ı, Afyonkarahisar/ Türkiye \\ E-Posta: omererbasan20@gmail.com ORCID: 0000-0001-7852-2747 \\ ** Dr. Öğr. Üyesi, Afyon Kocatepe Üniversitesi, Eğitim Fakültesi, Afyonkarahisar/ Türkiye \\ E-Posta: merkol@aku.edu.tr \\ ORCID: 0000-0002-1363-1894
}

$\ddot{O} z$

Bu araştırmanın amacl, sını f̈̈̆retmenlerinin çevre bilgilerinin, çevre sorunlarına yönelik tutumlarının ve çevre davranış düzeylerinin belirlenmesidir. Araştırmada bu düzeylere cinsiyet, kıdem, çalışılan yerleşim yeri, eğitim durumu, çevreyle ilgili sivil toplum kuruluşuna üyelik ve çevreyle ilgili proje çalışması yapıp yapmama değiş̧kenleri açısından da bakılmıştır. Araştırmada tarama yöntemi kullanılmıştır. Araştırmanın çalışma grubunu 2016-2017 eğitim öğretim yılında Afyonkarahisar ilinde bulunan devlet ilkokullarında görev yapan 371 sını öğretmeni oluşturmaktadır. Araştırmada veri toplama aracı olarak çevre bilgi testi, çevre sorunlarına yönelik tutum ölçeği ve çevre davranıs ölçeği kullanılmıştır. Elde edilen veriler SPSS 20 istatistik programı kullanılarak analiz edilmiştir. Verilerin analizinde betimsel istatistik, ilişkisiz örneklemler için $t$-testi ve tek yönlü varyans analizi kullanılmıştır. Araştırma sonucunda sını öğretmenlerinin çevre davranış ve çevre bilgi düzeylerinin orta, çevre sorunlarına yönelik tutum düzeylerinin yüksek olduğu belirlenmiştir. Ayrıca öğretmenlerin bilgi, tutum ve davranış puanlarının cinsiyet, eğitim durumu ve sivil toplum kuruluşuna üyelik durumuna göre değişmediği belirlenirken kıdem, yerleşim yeri ve proje çalışması yapıp yapmama değişkenlerine göre farklılıkların olduğ $u$ görülmüştür.

Anahtar Kelimeler: Çevre bilgisi, Çevre sorunlarına yönelik tutum, Çevre davranış, Sınıföğretmeni

\footnotetext{
${ }^{1}$ Bu çalışma Ömer Erbasan'ın “Öğretmenlerin Çevre Okuryazarlıklarının Bazı Değişkenler Açısından Incelenmesi" başlıklı yüksek lisans tez çalışmasından yararlanılarak hazırlanmıştır.
} 


\title{
Investigation of Environmental Knowledge, Attitudes and Behaviors of Primary School Teachers
}

$*$

\begin{abstract}
The purpose of this research is to determine the environmental knowledge, attitudes towards environmental problems and environmental behaviors of primary school teachers. In this study, the levels were also examined in terms of gender, seniority, residential area of workplace, educational background, membership to the non-governmental organizations related to the environment and availability of previous project experience on environment. Survey method was used in the study. The study group of the study is composed of 371 class teachers working in state primary schools in the province of Afyonkarahisar in the academic year of 2016-2017. Environment information test, attitude scale towards environmental problems and environmental behavior scale were used as data collection tools in the study. The data obtained were analyzed by using the SPSS 20 statistical program. Independent-samples $t$-test, and one way ANOVA were used in the analysis of results obtained from this study. As a result of the research, it was determined that both primary school teachers' environment behavior levels and their environmental knowledge levels are moderate and their attitudes towards about environmental problems are high. Furthermore, while it was determined that the knowledge, attitude and behavior scores of the teachers did not change according to gender, educational background and membership to non-governmental organizations, it was observed that there were differences in terms of the variables of seniority, residential area of workplace and availability of previous project experience on environment.
\end{abstract}

Keywords: Environmental knowledge, Attitude towards environmental problems, Environmental behavior, Primary school teachers 


\section{Giriş}

Çevre, "İnsanın veya herhangi bir canlının yaşadığı ortam" olarak tanımlamaktadır (Özey, 2009, s.1). Bu ortam içerisinde yer alan canlı ve cansız unsurlar arasındaki uyum, çevrenin devamlılığ için oldukça önemlidir. Ancak bu uyum, sistemin canlı unsurlarından biri olan insan eliyle zaman içerisinde bozulmaya başlamıştır.

"İnsan yaratıldığı günden itibaren doğayla iç içe yaşamaya başlamış ve bir süre onun verdikleriyle yetinmiştir. İnsan dışındaki diğer canlılar, mevcut doğa koşullarına uyum sağlamaya çalışırken insan, geliştikçe elindeki teknolojiden de faydalanmak suretiyle doğal çevre koşullarını değiştirerek doğayı kendi denetimi altına almak istemiştir" (Yıldız, Sipahioğlu ve Yılmaz, 2000). Bu denetime alma isteği karşısında yapılan yanlışlar, zaman içerisinde çevre sorunları olarak gün yüzüne çıkmıştır. Sever ve Yalçınkaya'ya (2012) göre özellikle sanayi devrimi ile birlikte insanın doğaya egemen olduğu aşamaya geçilmiş ve bu güç dengesinin insanın lehine değişmesi, dünya üzerindeki kaynakların hızlı ve bilinçsiz şekilde tüketilmesi ve çevresel sorunların başlangıcı ile sonuçlanmıştır.

Kısa bir zaman dilimi içerisinde çevre sorunlarının insanlı̆̆ın gündemini meşgul edecek seviyede artmasının ardında, insanoğlunun çevreyle ilgili sahip olduğu yanlış bir anlayış etkili olmuştur. Karabıçak ve Armağan'a (2004) göre başlangıçta insanların çevre ile ilgili genel kanısı, çevresel kaynakların sınırsız olduğu ve Dünya'nın kendisini yenileme kapasitesinin yeterli olduğu şeklindedir. Ancak bu düşüncenin yanlışlığı; kaynakların hızla azalması, ihtiyaçların çevre tarafından yeterince karşılanamaması ve çevre kirliliğinin insan sağlığını tehlikeye sokacak seviyeye ulaşması gibi acı gerçekler gün yüzüne çıkınca anlaşılmıştır. Bu yaygın ve yanlış anlayışın, çevre eğitiminin öneminin artmasına da sebep olduğu söylenebilir. Nitekim çevre sorunlarının önlenmesi ve çevrenin eski sağlıklı haline dönebilmesinin yollarını aramak için yapılan birçok uluslararası konferansın (Birleşmiş Milletler Birinci Çevre Konferansı, I. ve II. İklim Konferansı, Rio Zirvesi, II. Birleşmiş Milletler Çevre ve Kalkınma Konferansı vb.) sonucunda varılan ortak çözüm önerilerinin başında çevre eğitiminin yaygınlaştırılmasının geldiği görülmektedir.

Vaughan, Gack, Solorazano ve Ray (2003) çevre eğitimini, bireylerin çevrelerinden haberdar oldukları ve gelecek kuşaklar için çevre sorunlarını çözmek için bilgi, değer, beceri ve deneyim kazanacakları sürekli bir öğrenme 
süreci olarak tanımlamıştır. Çevre eğitiminin en önemli hedeflerinin başında, gündelik yaşam pratiklerimizin çevre üzerindeki etkisinin farkına vararak çevreye zarar veren davranışlarımızdan sakınıp çevre dostu seçimlere yönelmek gelmektedir (Özdemir, 2016, s.117). Kahyaoğlu'na (2009) göre günümüzde çevre sorunları sadece teknoloji veya yasalarla çözülebilecek bir sorun olmanın ötesine geçerek, çözümü ancak bireysel davranışların değişmesi ile mümkün olan bir sorun haline gelmiştir. Davranışların değişmesi için tutum ve değer yargılarının değişmesi oldukça önemlidir. Çevreye karşı pozitif tutum ve değer yargılarının oluşması ise çevre eğitimi ile gerçekleştirilebilir.

Eğitimin, öğrencilerde iyi tanımlanmış hedeflere yönelik kasıtlı olarak değişim meydana getirme süreci olduğu düşünülürse, çevre eğitimi de öğrencilerin çevreyle ilgili özel hedefleri yerine getirme süreci anlamına gelmektedir. Bu tür hedefler üç kategoride bilişsel, duyuşsal ve davranışsal olarak görülebilir (Schaefer, 1980, s.3). Çevre eğitiminin bilişsel boyutu, doğanın yapısı ve işleyişini, insan doğa ilişkisini ve doğa üzerindeki insan etkilerinin gelecekteki sonuçlarını bilme, tanıma ve öngörme vb. şeklindeki yeterliklere karşlık gelmektedir. Duyuşsal boyut, çevre eğitiminin en karakteristik özelliğini oluştururken bilme ve tanımanın ötesinde, canlı ve cansız diğer varlıklarla empati içine girme, duygusal bağlar kurma, önemseme, değer verme, koruyucu tutumlar sergileme gibi çevre eğitiminin özünü oluşturmaktadır. Davranışsal boyutu çağımızın karmaşık sorunlarıyla baş edebilme yetkinliğini kazandırmaya yönelik bir süreç olarak tanımlanabilir (Özdemir, 2016, s.3).

Eğitimin erken yaşlardaki önemi ve etkisi göz önünde bulundurulursa çevre eğitiminin de erken yaşlarda başlatılmasının ne kadar önemli olduğu daha iyi anlaşlacaktır. Bu anlamda sınıf öğretmenlerinin çevre bilgilerinin, tutumlarının ve davranışlarının çocukların çevre eğitimi üzerinde belirleyici olacağını söylemek yanlış olmayacaktır. Çünkü eğitim kalitesinin en önemli belirleyicileri arasında öğretmenler yer almaktadır. Genç ve Genç (2013) öğretmenlerin çevreye duyarlı, çevre sorunlarına çözmeye gönüllü ve çevreye olumlu tutum geliştiren bireyler olmaların, yetiştirecekleri öğrencileri de bu şekilde eğitmeleri bakımından önemli olduğunu belirtmiştir. Karataş (2013) çevre bilinciyle toplumu oluşturan bireylere bilgi, tutum ve yararlı davranışların kazandırılması noktasında öğretmenlere önemli görevler düştüğünü, çevre bilincine sahip bir öğretmenin öğrencilerine doğayı sevmenin ve korumanın önemini aşılayabileceğini ve bunun da daha yaşanabilir bir dünyanın garantisi olabileceğini belirtmektedir. Bu anlamda çalışmamızın temel amacı; 
erken yaşlardan itibaren çocukların eğitiminde söz sahibi olan sınıf öğretmenlerinin çevreye yönelik bilgi, tutum ve davranış düzeylerinin belirlenmesidir. Bu temel amaç doğrultusunda aşağıda verilen alt problemlere cevap aranmıştır:

1. Sınıf öğretmenlerinin çevre bilgileri hangi düzeydedir ve bu düzey cinsiyete, kıdeme, çalışılan yerleşim yerine, eğitim durumuna, çevreyle ilgili sivil toplum kuruluşuna üyelik durumuna ve çevreyle ilgili proje çalışması yapıp yapmama durumuna göre anlamlı bir farklılık göstermekte midir?

2. Sınıf öğretmenlerinin çevre sorunlarına yönelik tutumları hangi düzeydedir ve bu düzey cinsiyete, kıdeme, çalışılan yerleşim yerine, eğitim durumuna, çevreyle ilgili sivil toplum kuruluşuna üyelik durumuna ve çevreyle ilgili proje çalışması yapıp yapmama durumuna göre anlamlı bir farklılık göstermekte midir?

3. Sınıf öğretmenlerinin çevre davranışları hangi düzeydedir ve bu düzey cinsiyete, kıdeme, çalışılan yerleşim yerine, eğitim durumuna, çevreyle ilgili sivil toplum kuruluşuna üyelik durumuna ve çevreyle ilgili proje çalışması yapıp yapmama durumuna göre anlamlı bir farklılık göstermekte midir?

\section{Yöntem}

\section{Araştırmanın Modeli}

Sını öğretmenlerinin çevreye yönelik bilgi, tutum ve davranış düzeylerinin bazı değişkenler açısından incelenmesini amaçlayan bu araştırma, tarama (survey) modelinde betimsel bir çalışmadır. "Tarama modelleri, geçmişte ya da halen var olan bir durumu var olduğu şekliyle betimlemeyi amaçlayan araştırma yaklaşımlarıdır" (Karasar, 2015, s.77).

\section{Çalışma Grubu}

Çalışmanın evrenini 2016-2017 eğitim öğretim yılında Afyonkarahisar İlinde resmi ilkokullarda görev yapan sınıf öğretmenleri oluştururken örneklemini 
ise 2016-2017 eğitim öğretim yılında Afyonkarahisar İlinde resmi ilkokullarda görev yapan 371 sınıf öğretmeni oluşturmaktadır. Bu öğretmenlere ilişkin bilgiler Tablo 1'de sunulmuştur.

Tablo 1. Çalışma grubunun demografik değişkenlere göre dağılımları

\begin{tabular}{lccc}
\hline Değişken & Kadın & F & \% \\
\hline Cinsiyet & Erkek & 197 & 53.1 \\
& Toplam & 174 & 46.9 \\
& $0-5$ yıl & 371 & 100.0 \\
\hline Mesleki Kıdem & $6-10$ yıl & 109 & 29.4 \\
& $11-15$ yıl & 96 & 25.9 \\
& $16-20$ yıl & 55 & 14.8 \\
& 21 yıl ve üzeri & 46 & 12.4 \\
& Toplam & 65 & 17.5 \\
& İl & 371 & 100.0 \\
\hline Çalışılan Yerleşim Yeri & İçe & 135 & 36.4 \\
& Kasaba-köy & 121 & 32.6 \\
& Toplam & 115 & 31.0 \\
& Lisans & 371 & 100.0 \\
\hline Eğitim Durumu & 323 & 87.1 \\
& Lisansüstü & 48 & 12.9 \\
& Toplam & 371 & 100.0 \\
\hline STK Üyelik & Evet & 34 & 9.2 \\
& Hayır & 337 & 90.8 \\
& Toplam & 371 & 100.0 \\
\hline Proje & Evet & 61 & 16.4 \\
& Hayır & 310 & 83.6 \\
& Toplam & 371 & 100.0 \\
\hline
\end{tabular}

Tablo 1'e bakıldığında araştırmaya katılan öğretmenlerin \%53.1'inin kadın, \%29.4'ünün 0-5 yıl arası mesleki kıdeme sahip ve \%36.4'ünün il merkezinde görev yapan öğretmenler olduğu görülmektedir. Bununla birlikte öğretmenlerin az bir kısmının (\%12.9) lisans üstü eğitim yaptığı görülmektedir. Yine çevre ile ilgili bir sivil toplum kuruluşuna üye öğretmenler (\%9.2) ile konuyla ilgili proje çalışması yapan (\%16.4) öğretmenlerin oran olarak az olduğu anlaşılmaktadır.

\section{Veri Toplama Araçları}

Araştırmanın verilerini toplayabilmek için Çevre Bilgi Testi, Çevre Sorunlarına Yönelik Tutum Ölçeği ve Çevre Davranış Ölçeği kullanılmıştır. 
Çevre Bilgi Testi: Altınöz (2010) tarafından geliştirilen test, çoktan seçmeli 15 maddeden oluşmaktadır. Testte her bir madde beş seçeneklidir ve her bir sorunun değeri 1 puan olarak belirlenmiştir. Testten alınabilecek maksimum puan 15 ve minimum puan 0 'dır (Altınöz, 2010). Çalışmamızda testin güvenirliğini belirlemek amacıyla yapılan KR-20 değeri .63 bulunmuştur.

Çevre Sorunlarına Yönelik Tutum Ölçeği: Aksu (2009) tarafından geliştirilen ölçek toplam 11 maddeden oluşmaktadır. Likert tipinde olan tutum ölçeği, olumlu ifadeler için 5-4-3-2-1, olumsuz ifadeler için 1-2-3-4-5 şeklinde puanlandırılmıştır. Yüksek puan çevre sorunlarına yönelik olumlu tutumu, düşük puan ise çevre sorunlarına yönelik olumsuz tutumu göstermektedir. Ölçekten alınabilecek en düşük puan 11, en yüksek puan 55'dir. Yapı geçerliliğini araştırmak amacı ile yapılan faktör analizi sonucunda ölçeğin KMO değeri 0,789 ve Barlett değeri ise 309,623 olarak bulunmuştur (Aksu, 2009). Çalışmamız için ölçeğin güvenirlik katsayısı .83 bulunmuştur.

Çevre Davranış Ölçeği: Orijinali Goldman, Yavetz ve Pe'er (2006) tarafından geliştirilen çevre davranış ölçeğinin Türkçe uyarlama çalışmasını Timur ve Yılmaz (2013) yapmıştır. Beşli likert tipinde (1=Hiçbir zaman, 2=Nadiren, 3=Bazen, 4=Genellikle, 5=Her zaman) 20 maddeden oluşan ölçeğin geneli için Cronbach Alpha güvenirlik katsayısı .85 bulunmuştur. Elde edilen sonuçlar ölçeğin Türkiye'de de kullanılabileceğini göstermiştir (Timur ve Yılmaz, 2013). Çalışmamız için ölçeğin güvenirlik katsayısı .79 bulunmuştur.

\section{Verilerin Analizi}

Öğretmenlerin verdikleri cevaplar SPSS 20 paket programı ile analiz edilmiştir. Verilerin dağılımının normalliğine çarpıklık ve basıklık) değerleri ile bakılmıştır. Çalışmadaki verilerin çarpıklık ve basıklık katsayısı +1 ve -1 değerleri arasındadır. Morgan, Leech, Gloeckner ve Barret'e (2004, s.49) göre genel geçer kural olarak, çarpıklık katsayısının $+1,-1$ arası değerlerini normal dağılım ölçüsü olarak kabul etmeyi önermektedirler. Araştırmada, ön koşullarından birisi olarak normal dağılımın esas alındığı parametrik istatistikler yapılmıştır Öğretmenlerin kullanılan veri toplama araçlarından aldıkları puanla- 
rının cinsiyete, eğitim durumuna, çevreyle ilgili sivil toplum kuruluşuna üyelik durumuna ve çevre ile ilgili proje çalışması yapma durumuna göre farklılaşıp farklılaşmadığını belirlemek amacıyla ilişkisiz (bağımsız) gruplar t-testi kullanılmıştır. Kıdem ve çalışılan yerleşim yeri değişkenlerine göre istatistiksel olarak anlamlı bir farklılık olup olmadığının belirlenmesi için ise tek yönlü varyans analizi (ANOVA) testi uygulanmıştır. Grupların varyanslarının eşitliği için Levene testi sonucuna bakılmış ve grupların varyansları arasında anlamlı bir farklılık görülmemiştir. ANOVA testi sonucu çıkan anlamlı farkların hangi gruplar arasında olduğunu görmek amacıyla: varyansların eşitliği sağlandığından ve gruplardaki örneklem sayıları arasında fark olduğundan Sheffe testi tercih edilmiştir.

\section{Bulgular}

Araştırmanın bulguları, araştırmanın problemlerine göre sırasıyla sunulmuştur.

\section{Öğretmenlerin Çevre Bilgilerine İlişkin Bulgular}

Öğretmenlerin çevre bilgi düzeylerine ilişkin veriler Tablo 2'de sunulmuş ve yorumlanmiştır.

Tablo 2. Sını öğretmenlerinin çevre bilgi düzeyleri

\begin{tabular}{ccccc}
\hline & Min. & Max. & $\overline{\mathbf{X}}$ & S \\
\hline Bilgi & 0 & 15 & 8.54 & 2.80 \\
\hline
\end{tabular}

Tablo 2'de görüldüğü üzere öğretmenlerin aldıkları toplam puanın ortalaması $\bar{X}=8.54$, standart sapması $S=2.80$ olarak hesaplanmıştır. Bu değere göre öğretmenlerin çevre bilgilerinin orta düzeyde olduğu söylenebilir.

Öğretmenlerin çevre bilgi testinden aldıkları puanların ortalamasının cinsiyete göre farklılaşıp farklılaşmadığını ortaya koymak amacıyla yapılan ilişkisiz örneklemler için t testi sonuçları aşağıda Tablo 3 'te sunulmuştur.

Tablo 3. Cinsiyete göre çevre bilgi puanları arasındaki farklılı̆̆a ilişkin sonuçlar

\begin{tabular}{cccccccc}
\hline & Cinsiyet & $\mathbf{N}$ & $\overline{\mathbf{X}}$ & $\mathbf{S}$ & $\mathbf{s d}$ & $\mathbf{t}$ & $\mathbf{p}$ \\
\hline \multirow{2}{*}{ Bilgi } & Kadın & 197 & 8.74 & 2.65 & \multirow{2}{*}{369} & \multirow{2}{*}{1.440} & \multirow{2}{*}{0.151} \\
& Erkek & 174 & 8.32 & 2.96 & & & \\
\hline
\end{tabular}


Tablo 3'te görüldüğü üzere çevre bilgi testi puanları bakımından kadın öğretmenlerin ortalaması $(\overline{\mathrm{X}}=8.74)$, erkek öğretmenlerin ortalamasından $(\overline{\mathrm{X}}=8.32)$ yüksektir. Ancak analiz sonuçlarına göre öğretmenlerin çevre bilgi düzeyleri cinsiyetlerine göre anlamlı bir farklılık göstermemiştir ( $p>0.05)$. $\mathrm{Bu}$ bulguya göre öğretmenlerin çevre bilgi düzeylerinin cinsiyete göre değişmediği söylenebilir.

Öğretmenlerin çevre bilgi testinden aldıkları puanların ortalamasının k1demlerine göre farklılaşıp farklılaşmadığını ortaya koymak amacıyla yapılan tek yönlü varyans analizi sonuçları aşağıda Tablo 4'te sunulmuştur.

Tablo 4. Kıdemlere göre çevre bilgi puanları arasındaki farklılı̆̆a ilişkin sonuçlar

\begin{tabular}{lccccc}
\hline Varyansın Kaynağı & Kareler Toplamı & sd & Kareler Ortalaması & F & P \\
\hline Gruplar Arası & 68.667 & 4 & 17.167 & & \\
Gruplar İçi & 2839.349 & 366 & 7.758 & 2.213 & 0.067 \\
Toplam & 2908.016 & 370 & & & \\
\hline
\end{tabular}

Tablo 4'te görüldüğü üzere öğretmenlerin çevre bilgi testi puanları arasinda istatistiksel olarak anlamlı bir fark gözlenmemiştir ( $>0.05$ ). Bu bulguya göre öğretmenlerin çevre bilgi düzeylerinin kıdeme göre değişmediği söylenebilir.

Öğretmenlerin çevre bilgi testinden aldıkları puanların ortalamasının çalışılan yerleşim yerine göre farklılaşıp farklılaşmadığını ortaya koymak amacıyla yapılan tek yönlü varyans analizi sonuçları aşağıda Tablo 5'te sunulmuştur.

Tablo 5. Çalışılan yerleşim yerine göre çevre bilgi puanları arasındaki farkhlığa ilişkin sonuçlar

\begin{tabular}{lccccc}
\hline Varyansın Kaynağ1 & Kareler Top. & sd & Kareler Ort. & F & P \\
\hline Gruplar Arası & 14.335 & 2 & 7.167 & & \\
Gruplar İंci & 2893.681 & 368 & 7.863 & .911 & 0.403 \\
Toplam & 2908.016 & 370 & & & \\
\hline
\end{tabular}

Tablo 5'te görüldüğüü üzere öğretmenlerin çalıştıkları yerleşim yerine göre çevre bilgi düzeyleri arasında istatistiksel olarak anlamlı bir fark gözlenmemiştir ( $>00.05$ ). Bu bulguya göre öğretmenlerin çevre bilgi düzeylerinin çallşılan yerleşim yerine göre değişmediği söylenebilir. 
Öğretmenlerin çevre bilgi testinden aldıkları puanların ortalamasının eğitim durumuna göre farklılaşıp farklılaşmadığını ortaya koymak amacıyla yapılan ilişkisiz örneklemler için $\mathrm{t}$ testi sonuçları aşağıda Tablo 6'da sunulmuştur.

Tablo 6. Eğitim durumuna göre çevre bilgi puanlarn arasındaki farkhllı̆a ilişkin sonuçlar

\begin{tabular}{cccccccc}
\hline & Eğitim Durumu & $\mathbf{N}$ & $\overline{\mathbf{X}}$ & $\mathbf{S}$ & $\mathbf{s d}$ & $\mathbf{t}$ & $\mathbf{p}$ \\
\hline \multirow{2}{*}{ Bilgi } & Lisans & 323 & 8.50 & 2.62 & 53,794 & -.540 & 0.591 \\
& Lisansüstü & 48 & 8.81 & 3.82 & & & \\
\hline
\end{tabular}

Tablo 6'da görüldüğ̈ü üzere çevre bilgi testi puanları bakımından lisansüstü mezun öğretmenlerin ortalaması ( $\overline{\mathrm{X}}=8.81$ ), lisans mezunu öğretmenlerin ortalamasından $(\overline{\mathrm{X}}=8.50)$ daha yüksektir. Ancak analiz sonuçlarına göre öğretmenlerin çevre bilgi düzeyleri eğitim durumlarına göre anlamlı bir farklllık göstermemiştir ( $p>0.05)$. Bu bulguya göre öğretmenlerin çevre bilgi düzeylerinin eğitim durumuna göre değişmediği söylenebilir.

Öğretmenlerin çevre bilgi testinden aldıkları puanların ortalamasının çevreyle ilgili sivil toplum kuruluşuna üyelik durumuna göre farklılaşıp farkl1laşmadığını ortaya koymak amacıyla yapılan ilişkisiz örneklemler için t testi sonuçları aşağıda Tablo 7'de sunulmuştur.

Tablo 7. Çevreyle ilgili sivil toplum kuruluşuna üyelik durumuna göre çevre bilgi puanları arasındakı farklılı̆̆a ilişkin sonuçlar

\begin{tabular}{cccccccc}
\hline & Üyelik & $\mathbf{N}$ & $\overline{\mathbf{X}}$ & $\mathbf{S}$ & $\mathbf{s d}$ & $\mathbf{t}$ & $\mathbf{p}$ \\
\hline \multirow{2}{*}{ Bilgi } & Üyeyim & 34 & 8.85 & 2.90 & \multirow{2}{*}{369} & \multirow{2}{*}{0.673} & \multirow{2}{*}{0.502} \\
& Ü.değilim & 337 & 8.51 & 2.80 & & & \\
\hline
\end{tabular}

Tablo 7'de görüldüğü üzere çevre bilgi testi puanları bakımından çevreyle ilgili sivil toplum kuruluşuna üye öğretmenlerin ortalaması ( $\bar{X}=8.85)$, çevreyle ilgili sivil toplum kuruluşuna üye olmayan öğretmenlerin ortalamasından $(\overline{\mathrm{X}}=8.51)$ daha yüksektir. Ancak analiz sonuçlarına göre öğretmenlerin çevre bilgi düzeyleri, çevreyle ilgili sivil toplum kuruluşuna üyelik durumuna göre anlamlı bir farklılık göstermemiştir ( $\mathrm{p}>0.05$ ). Bu bulguya göre öğretmenlerin çevre bilgi düzeylerinin, çevreyle ilgili sivil toplum kuruluşuna üyelik durumuna göre değişmediği söylenebilir. 
Öğretmenlerin çevre bilgi testinden aldıkları puanların ortalamasının çevreyle ilgili proje çalışmaları yapma durumuna göre farklılaşıp farklılaşmadığını ortaya koymak amacıyla yapılan ilişkisiz örneklemler için $t$ testi sonuçları aşağıda Tablo 8'de sunulmuştur.

Tablo 8. Çevre eğitimiyle ilgili proje çalışması yapma durumuna göre çevre bilgi puanları arasındakı farklılı̆̆a ilişkin sonuçlar

\begin{tabular}{cccccccc}
\hline & Proje & $\mathbf{N}$ & $\overline{\mathbf{X}}$ & $\mathbf{S}$ & $\mathbf{s d}$ & $\mathbf{t}$ & $\mathbf{p}$ \\
\hline \multirow{3}{*}{ Bilgi } & Evet & 61 & 9.16 & 2.69 & 369 & 1.895 & 0.059 \\
& Hayır & 310 & 8.42 & 2.81 & & & \\
\hline
\end{tabular}

Tablo 8'de görüldüğü üzere çevre bilgi testi puanları bakımından çevreyle ilgili proje çalışması yapan öğretmenlerin ortalaması ( $\bar{X}=9.16)$, çevreyle ilgili proje çalışması yapmayan öğretmenlerin ortalamasından $(\overline{\mathrm{X}}=8.42)$ daha yüksektir. Ancak analiz sonuçlarına göre öğretmenlerin çevre bilgi düzeyleri çevreyle ilgili proje yapma durumlarına göre anlamlı bir farklılık göstermemiştir ( $>>0.05$ ). Bu bulguya göre çevreyle ilgili proje çalışması yapmanın çevre bilgisi üzerinde anlamlı bir etkisinin olmadığı söylenebilir.

\section{Öğretmenlerin Çevre Sorunlarına Yönelik Tutumlarına İlişkin Bulgular}

Öğretmenlerin çevre sorunlarına yönelik tutum düzeylerine ilişkin veriler Tablo 9'da sunulmuş ve yorumlanmıştır.

Tablo 9. Öğretmenlerin çevre sorunlarına yönelik tutum düzeyleri

\begin{tabular}{ccccc}
\hline & Min. & Max. & $\overline{\mathbf{X}}$ & S \\
\hline Tutum & 26 & 55 & 44.68 & 6.38 \\
\hline
\end{tabular}

Tablo 9'da görüldüğü üzere tutum ölçeğinde öğretmenlerin aldıkları toplam puanların ortalaması $\bar{X}=44.68$, standart sapması $S=6.38$ olarak bulunmuştur. Bu değere göre öğretmenlerin çevre sorunlarına yönelik tutumlarının yüksek düzeyde olduğu söylenebilir.

Öğretmenlerin çevre sorunlarına yönelik tutum ölçeğinden aldıkları puanların ortalamasının cinsiyete göre farklılaşıp farklılaşmadığını ortaya koymak amacıyla yapılan ilişkisiz örneklemler için $t$ testi sonuçları aşağıda Tablo 10 'da sunulmuştur. 
Tablo 10. Cinsiyete göre çevre sorunlarına yönelik tutum puanlarn arasındaki farklılı̆̆a ilişkin sonuçlar

\begin{tabular}{cccccccc}
\hline & Cinsiyet & $\mathbf{N}$ & $\overline{\mathbf{X}}$ & $\mathbf{S}$ & $\mathbf{s d}$ & $\mathbf{t}$ & $\mathbf{p}$ \\
\hline \multirow{2}{*}{ Tutum } & Kadın & 197 & 45.18 & 6.00 & \multirow{2}{*}{348.245} & \multirow{2}{*}{1.599} & 0.111 \\
& Erkek & 174 & 44.11 & 6.77 & & & \\
\hline
\end{tabular}

Tablo 10'da görüldüğü üzere çevre sorunlarına yönelik tutum puanları bakımından kadın öğretmenlerin ortalaması ( $\bar{X}=45.18)$ erkek öğretmenlerin ortalamasından $(\overline{\mathrm{X}}=44.11)$ daha yüksektir. Ancak analiz sonuçlarına göre öğretmenlerin tutumları cinsiyetlerine göre anlamlı bir farklılık göstermemiştir ( $p>0.05)$. Bu bulguya göre öğretmenlerin çevre sorunlarına yönelik tutumlarının cinsiyete göre değişmediği söylenebilir.

Öğretmenlerin tutum ölçeğinden aldıkları puanların ortalamasının k1demlerine göre farklılaşıp farklılaşmadığını ortaya koymak amacıyla yapılan tek yönlü varyans analizi sonuçları aşağıda Tablo 11'de sunulmuştur.

Tablo 11. Kıdemlere göre çevre sorunlarına yönelik tutum puanları arasındaki farklıliğa ilişkin tek yönlï varyans analizi sonuçları

\begin{tabular}{cccccc}
\hline Varyansın Kaynağı & Kareler Toplamı & sd & Kareler Ortalaması & F & P \\
\hline Gruplar Arası & 238.710 & 4 & 59.678 & & \\
Gruplar İçi & 14837.759 & 366 & 40.540 & 1.472 & 0.210 \\
Toplam & 15076.469 & 370 & & & \\
\hline
\end{tabular}

Tablo 11'de görüldüğü üzere, öğretmenlerin kıdemlerine göre çevre sorunlarına yönelik tutum puanları arasında istatistiksel olarak anlamlı bir fark gözlenmemiştir ( $p>0.05$ ). Bu bulguya göre öğretmenlerin çevre sorunlarına yönelik tutumlarının kıdeme göre değişmediği söylenebilir.

Öğretmenlerin tutum ölçeğinden aldıkları puanların ortalamasının çalışılan yerleşim yerine göre farklılaşıp farklılaşmadığını ortaya koymak amacıyla yapılan tek yönlü varyans analizi sonuçları aşağıda Tablo 12'de sunulmuştur.

Tablo 12. Çalışılan yerleşim yerine göre çevre sorunlarna yönelik tutum puanları arasındaki farkalılığa ilişkin sonuçlar

\begin{tabular}{ccccccc}
\hline $\begin{array}{c}\text { Varyansın } \\
\text { Kaynağı }\end{array}$ & Kareler Toplamı & Sd & Kareler Ortalaması & F & P & $\begin{array}{c}\text { Anlamlı } \\
\text { Fark }\end{array}$ \\
\hline Gruplar Arası & 313.372 & 2 & 156.686 & & 0.0 & \\
Gruplar İçi & 14763.097 & 368 & 40.117 & 3.906 & 21 & $1-3$ \\
Toplam & 15076.469 & 370 & & & & \\
\hline
\end{tabular}


Tablo 12'de görüldüğü üzere öğretmenlerin çalıştıkları yerleşim yerine göre çevre sorunlarına yönelik tutum puanlarının en az ikisi arasında istatistiksel olarak anlamlı bir fark gözlenmiştir $[\mathrm{F}(2-368)=3.90, \mathrm{p}<0.05)]$. Test sonucunda hesaplanan etki büyüklüğü $\left(\eta^{2}=0.02\right)$ bu farkın düşük düzeyde olduğunu göstermektedir. Farklılığın hangi gruplar arasında olduğunu belirlemek amacıyla yapılan Scheffe çoklu karşılaştırma testi sonucunda, anlamlı farkın il merkezinde görev yapan öğretmenlerle $(\bar{X}=45.66)$ kasaba veya köyde görev yapan öğretmenler ( $\overline{\mathrm{X}}=43.42)$ arasında olduğu görülmektedir. Bu bulguya göre il merkezinde görev yapan öğretmenlerin çevre sorunlarına yönelik tutum düzeylerinin, köy veya kasabada görev yapan öğretmenlere göre daha yüksek olduğu söylenebilir.

Öğretmenlerin çevre sorunlarına yönelik tutum ölçeğinden aldıkları puanların ortalamasının eğitim durumuna göre farklılaşıp farklılaşmadığını ortaya koymak amacıyla yapılan ilişkisiz örneklemler için $t$ testi sonuçları aşağıda Tablo 13'te sunulmuştur.

Tablo 13. Eğitim durumuna göre çevre sorunlarına yönelik tutum puanları arasındaki farklılı̆̆a ilişkin sonuçlar

\begin{tabular}{cccccccc}
\hline & Eğitim Durumu & $\mathbf{N}$ & $\overline{\mathbf{X}}$ & $\mathbf{S}$ & $\mathbf{s d}$ & $\mathbf{t}$ & $\mathbf{p}$ \\
\hline \multirow{2}{*}{ Tutum } & Lisans & 323 & 44.79 & 6.15 & \multirow{2}{*}{56.040} & \multirow{2}{*}{.727} & 0.470 \\
& Lisansüstü & 48 & 43.94 & 7.79 & & \\
\hline
\end{tabular}

Tablo 13'te görüldüğü üzere çevre sorunlarına yönelik tutum puanları bakımından lisans mezunu öğretmenlerin ortalaması ( $\overline{\mathrm{X}}=44.79)$, lisansüstü mezun öğretmenlerin ortalamasından $(\bar{X}=43.94)$ daha yüksektir. Ancak analiz sonuçlarına göre öğretmenlerin tutum puanları eğitim durumlarına göre anlamlı bir farklılık göstermemiştir ( $\mathrm{p}>0.05)$. Bu bulguya göre öğretmenlerin çevre sorunlarına yönelik tutumlarının, eğitim durumuna göre değişmediği söylenebilir

Öğretmenlerin çevre sorunlarına yönelik tutum ölçeğinden aldıkları puanların ortalamasının çevreyle ilgili sivil toplum kuruluşuna üyelik durumuna göre farklılaşıp farklılaşmadığını ortaya koymak amacıyla yapılan ilişkisiz örneklemler için $\mathrm{t}$ testi sonuçları aşağıda Tablo 14'te sunulmuştur.

Tablo 14. Çevreyle ilgili sivil toplum kuruluşuna üyelik durumuna göre çevre sorunlarına yönelik tutum puanları arasındaki farkalılığa ilişkin sonuçlar

\begin{tabular}{cccccccc}
\hline & Üyelik & $\mathbf{N}$ & $\overline{\mathbf{X}}$ & $\mathbf{S}$ & $\mathbf{s d}$ & $\mathbf{t}$ & $\mathbf{p}$ \\
\hline \multirow{2}{*}{ Tutum } & Üyeyim & 34 & 45.50 & 6.99 & \multirow{2}{*}{369} & \multirow{2}{*}{0.784} & \multirow{2}{*}{0.434} \\
& Ü.değilim & 337 & 44.60 & 6.32 & & \\
\end{tabular}


Tablo 14'te görüldüğü üzere çevre sorunlarına yönelik tutum puanları bakımından çevreyle ilgili sivil toplum kuruluşuna üye öğretmenlerin ortalaması ( $\bar{X}=45.50)$, çevreyle ilgili sivil toplum kuruluşuna üye olmayan öğretmenlerin ortalamasından $(\overline{\mathrm{X}}=44.60)$ daha yüksektir. Ancak analiz sonuçlarına göre öğretmenlerin tutumları, çevreyle ilgili sivil toplum kuruluşuna üyelik durumuna göre anlamlı bir farklılık göstermemiştir ( $p>0.05)$. Bu bulguya göre öğretmenlerin çevre sorunlarına yönelik tutumlarının, çevreyle ilgili sivil toplum kuruluşuna üyelik durumuna göre değişmediği söylenebilir.

Öğretmenlerin çevre sorunlarına yönelik tutum ölçeğinden aldıkları puanların ortalamasının çevreyle ilgili proje çalışmaları yapma durumuna göre farklılaşıp farklılaşmadığını ortaya koymak amacıyla yapılan ilişkisiz örneklemler için $\mathrm{t}$ testi sonuçları aşağıda Tablo $15^{\prime}$ te sunulmuştur.

Tablo 15. Çevre eğitimiyle ilgili proje çalışmaları yapma durumuna göre çevre sorunlarına yönelik tutum puanları arasındaki farklılı̆̆a ilişkin sonuçlar

\begin{tabular}{cccccccc}
\hline & Proje & $\mathbf{N}$ & $\overline{\mathbf{X}}$ & $\mathbf{S}$ & $\mathbf{s d}$ & $\mathbf{t}$ & $\mathbf{p}$ \\
\hline \multirow{2}{*}{ Tutum } & Evet & 61 & 46.74 & 6.20 & \multirow{2}{*}{369} & \multirow{2}{*}{2.776} & \multirow{2}{*}{0.006} \\
& Hayir & 310 & 44.28 & 6.35 & & & \\
\hline
\end{tabular}

Tablo 15'de görüldüğü üzere çevreyle ilgili proje çalışması yapan öğretmenlerin ortalaması ile $(\overline{\mathrm{X}}=46.74)$ çevreyle ilgili proje çalışması yapmayan öğretmenlerin ortalaması $(\overline{\mathrm{X}}=44.28)$ arasında anlamlı bir fark olduğu görülmektedir [t(369)=2.776, $\mathrm{p}<0.05]$. Bu bulguya göre çevreyle ilgili proje çalışması yapmanın çevre sorunlarına yönelik tutum üzerinde anlamlı bir etkisinin olduğu söylenebilir.

\section{Öğretmenlerin Çevre Davranışlarına İlişkin Bulgular}

Öğretmenlerin çevre davranış düzeylerine ilişkin veriler Tablo 16'da sunulmuş ve yorumlanmıştır.

Tablo 16. Öğretmenlerin çevre davranış düzeyleri

\begin{tabular}{ccccc}
\hline & Min. & Max. & $\overline{\mathbf{X}}$ & $\mathbf{S}$ \\
\hline Davranıs & 37 & 100 & 71.69 & 11.0 \\
\hline
\end{tabular}

Tablo 16'da görüldüğü üzere çevre davranış ölçeğinde öğretmenlerin aldıkları toplam puanların ortalaması $\bar{X}=71.69$, standart sapması $S=11.0$ olarak 
hesaplanmıştır. Bu değere göre öğretmenlerin çevre davranışlarının orta düzeyde olduğu söylenebilir.

Öğretmenlerin çevre davranış ölçeğinden aldıkları puanların ortalamasının cinsiyete göre farklılaşıp farklılaşmadığını ortaya koymak amacıyla yapılan ilişkisiz örneklemler için $t$ testi sonuçları aşağıda Tablo 17'de sunulmuştur.

Tablo 17. Cinsiyete göre çevre davranış puanları arasındaki farklılı̆̆a ilişkin sonuçlar

\begin{tabular}{cccccccc}
\hline & Cinsiyet & $\mathbf{N}$ & $\overline{\mathbf{X}}$ & $\mathbf{S}$ & sd & t & p \\
\hline \multirow{2}{*}{ Davranış } & Kadın & 197 & 71.75 & 10.54 & \multirow{2}{*}{369} & \multirow{2}{*}{0.089} & 0.929 \\
& Erkek & 174 & 71.64 & 11.55 & & & \\
\hline
\end{tabular}

Tablo 17'de görüldüğü üzere çevre davranış ölçeği puanları bakımından kadın öğretmenlerin ortalaması ( $\bar{X}=71.75)$, erkek öğretmenlerin ortalamasından $(\bar{X}=71.64)$ daha yüksektir. Ancak öğretmenlerin çevre davranış ölçeğinden aldıkları puanların ortalaması cinsiyete göre anlamlı bir farklılık göstermemiştir ( $\mathrm{p}>0.05)$. Bu bulguya göre öğretmenlerin çevre davranışlarının cinsiyete göre değişmediği söylenebilir.

Öğretmenlerin çevre davranış ölçeğinden aldıkları puanların ortalamasının kıdeme göre farklılaşıp farklılaşmadığını ortaya koymak amacıyla yapılan tek yönlü varyans analizi sonuçları aşağıda Tablo $18^{\prime}$ de sunulmuştur.

Tablo 18. Kıdemlere göre çevre davranış puanlarn arasındaki farklılı̆̆a ilişkin sonuçlar

\begin{tabular}{ccccccc}
\hline $\begin{array}{c}\text { Varyansın } \\
\text { Kaynağı }\end{array}$ & $\begin{array}{c}\text { Kareler } \\
\text { Toplamı }\end{array}$ & sd & $\begin{array}{c}\text { Kareler } \\
\text { Ortalaması }\end{array}$ & F & P & $\begin{array}{c}\text { Anlamlı } \\
\text { Fark }\end{array}$ \\
\hline Gruplar Arası & 2412.448 & 4 & 603.112 & & & $1-5$ \\
Gruplar İçi & 42423.741 & 366 & 115.912 & 5.203 & 0.00 & $2-5$ \\
Toplam & 44836.189 & 370 & & & & \\
\hline
\end{tabular}

Tablo 18'de görüldüğü üzere öğretmenlerin kıdemlerine göre çevre davranış puan ortalamalarının en az ikisi arasında istatistiksel olarak anlamlı bir fark gözlenmiştir $[\mathrm{F}(4-366)=5.203, \mathrm{p}<0.05)]$. Test sonucu hesaplanan etki büyüklüğü $\left(\eta^{2}=0.05\right)$ bu farkın orta düzeyde olduğunu göstermektedir. Farklılığın hangi gruplar arasında olduğunu belirlemek amaciyla yapılan Scheffe çoklu karşılaştırma testi sonucunda, anlamlı farkın 0-5 ( $\overline{\mathrm{X}}=70.20)$ ile 6-10 yıl $(\bar{X}=69.09)$ arası mesleki kıdeme sahip öğretmenler ile 21 yıl ve üzeri $(\bar{X}=76.29)$ mesleki kıdeme sahip öğretmenler arasında olduğu görülmüştür. Bu bulguya göre kıdemi daha fazla olan öğretmenlerin çevre davranış düzeylerinin, 
kıdemi az olan öğretmenlere göre anlamlı derecede yüksek olduğu söylenebilir.

Öğretmenlerin çevre davranış ölçeğinden aldıkları puanların ortalamasının çalışılan yerleşim yerine göre farklılaşıp farklılaşmadığını ortaya koymak amacıyla yapılan tek yönlü varyans analizi sonuçları aşağıda Tablo 19 'da sunulmuştur.

Tablo 19. Çalışılan yerleşim yerine göre çevre davranış puanlar arasındaki farklılı̆ga ilişkin sonuçlar

\begin{tabular}{ccccccc}
\hline $\begin{array}{c}\text { Varyansın } \\
\text { Kaynağı }\end{array}$ & $\begin{array}{c}\text { Kareler } \\
\text { Toplamı }\end{array}$ & sd & $\begin{array}{c}\text { Kareler } \\
\text { Ortalaması }\end{array}$ & F & P & $\begin{array}{c}\text { Anlamlı } \\
\text { Fark }\end{array}$ \\
\hline Gruplar Arası & 2769.006 & 2 & 1384.503 & & & $1-2$ \\
Gruplar İçi & 42067.182 & 368 & 114.313 & 12.112 & 0.00 & $1-3$ \\
Toplam & 44836.189 & 370 & & & & \\
\hline
\end{tabular}

Tablo 19'da görüldüğü üzere öğretmenlerin çalışllan yerleşim yerine göre çevre davranış puan ortalamalarının en az ikisi arasında istatistiksel olarak anlamlı bir fark gözlenmiştir $[\mathrm{F}(2-368)=12.112, \mathrm{p}<0.05)]$. Test sonucu hesaplanan etki büyüklüğü $\left(\eta^{2}=0.06\right)$ bu farkın orta düzeyde olduğunu göstermektedir. Farklılığın hangi gruplar arasında olduğunu belirlemek amacıyla yapılan Scheffe çoklu karşılaştırma testi sonucunda, anlamlı farkın il merkezinde görev yapan öğretmenler ( $\overline{\mathrm{X}}=75.27)$ ile ilçe ve kasaba veya köyde görev yapan öğretmenler ( $\overline{\mathrm{X}}=70.12$ ) arasında olduğu görülmektedir. Bu bulguya göre il merkezinde görev yapan öğretmenlerin çevre davranış düzeylerinin, ilçe merkezi ile kasaba veya köyde yaşayan öğretmenlere göre daha yüksek olduğu söylenebilir.

Öğretmenlerin çevre davranış ölçeğinden aldıkları puanların ortalamasının eğitim durumuna göre farklılaşıp farklılaşmadığını ortaya koymak amacryla yapılan ilişkisiz örneklemler için t testi sonuçları aşağıda Tablo 20'de sunulmuştur.

Tablo 20. Ĕ̆itim durumuna göre çevre davranış puanları arasındaki farklılı̆a ilişkin sonuçlar

\begin{tabular}{lccccccc}
\hline & Eğitim Durumu & $\mathbf{N}$ & $\overline{\mathbf{X}}$ & $\mathbf{S}$ & $\mathbf{s d}$ & $\mathbf{t}$ & $\mathbf{p}$ \\
\hline \multirow{2}{*}{ Davranış } & Lisans & 323 & 71.82 & 10.87 & \multirow{2}{*}{369} & \multirow{2}{*}{.541} & \multirow{2}{*}{.589} \\
& Lisansüstü & 48 & 70.90 & 12.00 & & & \\
\hline
\end{tabular}


Tablo 20'de görüldüğüu üzere çevre davranış ölçeği puanları bakımından lisans mezunu öğretmenlerin ortalaması ( $\bar{X}=71.82)$, lisansüstü mezun öğretmenlerin ortalamasından $(\overline{\mathrm{X}}=70.90)$ daha yüksektir. Ancak analiz sonuçlarına göre öğretmenlerin çevre davranış puanları eğitim durumlarına göre anlamlı bir farklılık göstermemiştir ( $p>0.05)$. Bu bulguya göre öğretmenlerin çevre davranışlarının eğitim durumuna göre değişmediği söylenebilir.

Öğretmenlerin çevre davranış ölçeğinden aldıkları puanların ortalamasının çevreyle ilgili bir sivil toplum kuruluşuna üyelik durumuna göre farklılaşıp farklılaşmadığını ortaya koymak amacıyla yapılan ilişkisiz örneklemler için t testi sonuçları aşağıda Tablo 21'de sunulmuştur.

Tablo 21. Çevreyle ilgili sivil toplum kuruluşuna üyelik durumuna göre çevre davranış puanları arasındaki farklılı̆̆a ilişkin sonuçlar

\begin{tabular}{cccccccc}
\hline & Üyelik & $\mathbf{N}$ & $\mathbf{X}$ & $\mathbf{S}$ & sd & t & p \\
\hline \multirow{2}{*}{ Davranış } & Üyeyim & 34 & 74.71 & 11.95 & \multirow{2}{*}{369} & \multirow{2}{*}{1.676} & 0.095 \\
& Ü.değilim & 337 & 71.39 & 10.88 & & & \\
\hline
\end{tabular}

Tablo 21'de görüldüğü üzere çevre davranış ölçeği puanları bakımından çevreyle ilgili sivil toplum kuruluşuna üye öğretmenlerin ortalaması $(\overline{\mathrm{X}}=74.71)$, çevreyle ilgili sivil toplum kuruluşuna üye olmayan öğretmenlerin ortalamasından ( $\bar{X}=71.39)$ daha yüksektir. Ancak analiz sonuçlarına göre öğretmenlerin çevre davranışları, çevreyle ilgili bir sivil toplum kuruluşuna üyelik durumuna göre anlamlı bir farklılık göstermemiştir ( $p>0.05$ ). Bu bulguya göre öğretmenlerin çevre davranışlarının, çevreyle ilgili sivil toplum kuruluşuna üyelik durumuna göre değişmediği söylenebilir.

Öğretmenlerin çevre davranış ölçeğinden aldıkları puanların ortalamasının çevreyle ilgili proje çalışmaları yapma durumuna göre farklılaşıp farkl1laşmadığını ortaya koymak amacıyla yapılan ilişkisiz örneklemler için t testi sonuçları aşağıda Tablo 22'de sunulmuştur.

Tablo 22. Çevre eğitimiyle ilgili proje çalışmaları yapma durumuna göre çevre davranış puanları arasındaki farklılı̆̆a ilişkin sonuçlar

\begin{tabular}{cccccccc}
\hline & Proje & $\mathbf{N}$ & $\overline{\mathbf{X}}$ & $\mathbf{S}$ & $\mathbf{s d}$ & $\mathbf{t}$ & $\mathbf{p}$ \\
\hline \multirow{2}{*}{ Davranış } & Evet & 61 & 78.87 & 10.01 & \multirow{2}{*}{369} & \multirow{2}{*}{5.807} & \multirow{2}{*}{0.000} \\
& Hayır & 310 & 70.29 & 10.65 & & & \\
\hline
\end{tabular}


Tablo 22'de görüldüğü üzere çevreyle ilgili proje çalışması yapan öğretmenlerin ortalaması ( $\overline{\mathrm{X}}=78.87)$ ile çevreyle ilgili proje çalışması yapmayan öğretmenlerin ortalaması ( $\overline{\mathrm{X}}=70.29)$ arasında anlamlı bir fark olduğu görülmekte$\operatorname{dir}[\mathrm{t}(369)=5.807, \mathrm{p}<0.05]$. Bu bulguya göre çevreyle ilgili proje çalışması yapmanın çevre davranışı üzerinde anlamlı bir etkisinin olduğu söylenebilir.

\section{Sonuç, Tartışma ve Öneriler}

Araştırmamızda sınıf öğretmenlerinin çevre bilgilerinin ve çevre davranışlarının orta düzeyde, çevre sorunlarına yönelik tutumlarının ise yüksek düzeyde olduğu sonucuna ulaşılmıştır. Literatür incelendiğinde öğretmenler ile yapılmış çalışmaların az sayıda olduğu görülmektedir. Aydemir (2007) ve Tungaç (2015) çalışmalarında benzer şekilde Fen Bilgisi öğretmenlerinin orta düzeyde çevre bilgisine sahip olduğu sonucuna ulaşmışlardır. Bunun d1şında Bilim (2012), Güler (2013), Karatekin (2011), Şerenli (2010) ve Timur (2011) öğretmen adaylarıyla yaptıkları çalışmalarda orta düzeyde çevre bilgisi sonucuna ulaşmışlardır. Bunun dışında literatürde farklı sonuçların yer aldığı çalışmalarda yer almaktadır. Owens (2000) öğretmenlerle yaptığı çalışmasında ortaokul öğretmenlerinin çevre bilgilerinin yeterli düzeyde olmad1ğını belirlemiştir. Yine Cutter (2002) ilköğretim öğretmenlerinin çevre bilgilerini yetersiz bulmuştur.

Owens (2000) ortaokul öğretmenlerinin çevre tutumlarının yüksek düzeyde olduğunu belirlemiştir. Aksu (2009) sinıf öğretmenleri ve fen bilgisi öğretmenleri ile olan çalışmasında benzer şekilde öğretmenlerin çevre tutumlarının yüksek düzeyle olduğu sonucuna ulaşmıştır. Yine Tungaç (2015) Fen Bilgisi öğretmenlerinin yüksek çevre tutumuna sahip olduğunu belirlemiştir. Literatürde farklı sonuçların yer aldığı çalışmalar da bulunmaktadır. Güven (2013); Köğce, Ünal ve Şahin (2009); Polat (2012) ve Şerenli (2010) öğretmen adaylarıyla yaptığ 1 çalışmalarda orta düzeyde çevre tutumu belirlemişlerdir. Bunun dişında Erol ve Gezer (2006) sınıf öğretmenliği lisans öğrencileriyle yaptığı çalışmalarında öğretmen adaylarının çevre sorunlarına yönelik tutumlarının genel olarak zayıf olduğu sonucuna ulaşmışlardır.

Karatekin (2011) yaptı̆̆ çalışmada öğretmen adaylarının orta düzeyde çevre davranış puanına sahip olduğu sonucuna ulaşmış ve öğretmen adaylarının katılım becerisi gerektiren çevre davranışlarında istekli olmadıklarını 
ve sorumluluk altına girmek istemediklerini belirtmiştir. Timur (2011) çalışmasında Fen Bilgisi öğretmen adaylarının orta düzeyde çevre davranışına sahip olduklarını belirlemiştir. Yine Bilim (2012), eğitim fakültesi öğrencileri ile yapmış olduğu çalışmada öğretmen adaylarının çevre davranış düzeylerini orta düzeyde bulmuştur. Ayrıca Kaya, Akıllı ve Sezek (2009), Esa (2010), Mcbeth ve Volk (2010) ve Şahin (2015) yaptıkları çalışmalarda benzer sonuçlara ulaşmışlardır. Bunun dışında Connell, Fien, Lee, Sykes ve Yencken (1999) ve Kibert (2000) çalışmalarında öğrencilerin düşük düzeyde çevre davranışına sahip olduklarını belirlemiştir.

Öğretmenlerin belirli bir konuyla ilgili tutumlarının öğretilen konunun niteliğini ve kalıcılığını etkilediği düşünüldügü̈nde, çevre sorunlarına yönelik tutumlarının yüksek olması olumlu değerlendirilebilir ancak çalışma bulgularının öğretmenlerin bu olumlu tutumlarını davranışa dönüştürmekte zorlandıklarını gösterdiği söylenebilir. Araştırmalar çevreye yönelik tutumların ve çevre bilgisinin yüksek olmasının, kişilerin çevreye zararlı davranışlar göstermesine yetmediğini göstermektedir (Erten, 2005). Morrone, Mancl ve Carr'a (2001, s.34) göre tam olarak okuryazar bir kişi sadece bilgiyle donatılan değil; bilgiyi eylemlere yol açan değerlerle birleştirebilen kişidir. Geleceğin çevrecilerini yetiştirecek olan öğretmenlerin tutumları yüksek düzeyde olsa da çevre bilgilerinin henüz istenilen düzeyde olmadığı görülmektedir. Bunun sebebi olarak öğretmenlerin lisans eğitimleri sırasında aldıkları çevre eğitiminin yetersiz olması gösterilebilir. Nitekim literatürde bu görüşümüzü destekleyen çalışmalar yer almaktadır. Maskan, Efe, Gönen ve Baran (2006) yaptıkları çalışmalarında, öğretmen adaylarının büyük çoğunluğunun Türkiye'de öğretmen yetiştiren yükseköğretim kurumlarında çevre eğitimi derslerinin yeterli verilmediğine, var olan derslerin içeriğinin çevreye ilişkin iyi davranış biçimi geliştirecek şekilde düzenlenmediğine inandıklarını belirlemişlerdir. Aydemir (2007) çalışmasının sonucunda, öğretmenlerin yeterli bir çevre eğitimini yükseköğrenimlerinde ve mezun olduktan sonra almadıklarını tespit etmiştir. Teksöz, Şahin ve Ertepinar (2010) da öğretmen adaylarıyla yaptıkları çalışmada öğretmen adaylarının çevre bilgilerinin yetersiz olduğu sonucuna ulaşmış ve bu durumu aldıkları çevre eğitiminin yetersizliği ile açıklamışlardır. Bununla birlikte yeterli ve nitelikli bir çevre eğitiminin bilgi seviyesinde, tutum ve davranışlarda olumlu yönde bir artş̧a neden olduğu çeşitli çalışmalarla ortaya konulmuştur (Aydın, 2008; Bradley, Waliczek ve Zajicek 1999; Deniş ve Genç, 2007; Güven, 2011; Kızıl, 2012; Yavuz, 2006). 
Araştırmamızda sınıf öğretmenlerinin bilgi, tutum ve davranış puanlarının cinsiyete göre değişmediği belirlenmiştir. Toplumsal cinsiyet rolleri arasındaki farkın gittikçe azaldığı günümüzde, öğretmenlerin yer aldığı bir çalışma grubunda cinsiyetler arası anlamlı bir farklılığın görülmemesi anlaşılabilir bir sonuç olarak değerlendirilebilir. Kıdem değişkenine göre farklılık incelendiğinde ise bilgi ve tutum açısından anlamlı bir farklılık görünmezken, 21 yıl ve üzeri mesleki kıdeme sahip öğretmenlerin çevre davranış düzeylerinin 0-5 yıl arası ile 6-10 yıl arası mesleki kıdeme sahip öğretmenlere göre orta düzeyde anlamlı derece daha yüksek olduğu belirlenmiştir. Bununla birlikte puanlar yerleşim yerine göre karşılaştırıldığında, il merkezinde görev yapan öğretmenlerin çevre davranış düzeylerinin, ilçe merkezi ile kasaba veya köyde yaşayan öğretmenlere göre daha yüksek olduğu sonucuna ulaşılmıştır. Yine il merkezinde görev yapan öğretmenlerin çevre tutum düzeylerinin, köy veya kasabada görev yapan öğretmenlere göre daha yüksek olduğu sonucuna ulaşılmıştır. İlde yaşayan öğretmenlerin tutum ve davranış puanlarının yüksek çıkmasının sebebi olarak, çevre sorunlarının şehirlerde köylere göre daha çok hissediliyor olması gösterilebilir. Büyük şehirlerde yaşayanlar çevre sorunlarına daha çok maruz kaldıkları için çevre sorunlarına yönelik tutumlarının ve davranışlarının daha yüksek çıkması beklenilen bir sonuç olarak düşünülebilir.

Bulgular eğitim durumuna göre incelendiğinde öğretmenlerin çevre davranışlarının, çevre sorunlarına yönelik tutumlarının ve çevre bilgilerinin eğitim durumuna göre değişmediği belirlenmiştir. Öğretmenlerin yüksek lisans eğitimi sırasında çevre ile ilgili bir ders almadıkları veya herhangi bir çalışma yapmadıkları varsayılırsa, lisans mezunu öğretmenler ile aralarında fark bulunmaması beklenilen bir sonuç olarak değerlendirilebilir. Fakat çalışmamızda yüksek lisans yapan öğretmenlerin ne tür çalışma yaptıkları veya hangi dersi aldıkları bilgisi yer almamaktadır. Araştırmamızda çevre ile ilgili bir sivil toplum kuruluşuna üyelik durumunun çevre bilgisi, tutumu ve davranışı üzerinde anlamlı bir etkisinin olmadığı sonucuna ulaşılmıştır. Benzer sonuçlara Uzun (2007), Aksu (2009), Ürey ve Şahin (2010), Karatekin (2011) de çalışmalarında ulaşmışlardır.

Araştırmamızda çevre eğitimiyle ilgili proje çalışması yapmanın çevre sorunlarına yönelik tutum ve çevre davranış puanları için anlamlı derecede etkisinin olduğu ancak çevre bilgisi için anlamlı bir etkisinin olmadığı sonu- 
cuna ulaşılmıştır. Çevre ile ilgili proje çalışması yapan veya proje çalışmalarına katılan öğretmenlerin çevre sorunlarına yönelik farkındalık kazandığı ve bu durumun onların tutumlarında ve davranışlarında olumlu etkisinin olduğu söylenebilir. Tungaç (2015) araştırmasında benzer şekilde, doğa eğitimi projelerine katılmış ve doğa eğitimi projesi hazırlamış olan öğretmenlerin çevresel tutum puanlarının bu projelere katılmamış ve bu tarz projeler düzenlememiş olan öğretmenlere göre daha yüksek olduğu sonucuna ulaşmıştir.

Araştırmamızın bulgularından yola çıkarak şu öneriler getirilebilir:

- Öğretmenlerin çevre sorunlarına yönelik tutumlarının yüksek düzeyde olmasına rağmen, çevre bilgileri ve çevre davranışlarının orta düzeyde olduğu belirlenmiştir. Öğretmenlerin çevre bilgilerini artırmak ve var olan tutumlarını davranışa dönüştürmelerini sağlayabilmek amacıyla bilgi-tutum-davranış boyutlarının dengeli ele alındığı uygulamalı hizmet içi eğitimler verilebilir.

- Çalışmanın çevre ile ilgili proje çalışması yapmanın çevre sorunlarına yönelik tutum ve çevre davranışı üzerinde olumlu yönde anlamlı etkisi olduğu sonucundan hareketle, öğretmenlerin proje çalışması yapmalarını veya konuyla ilgili proje çalışmalarına katılmalarını sağlayıcı adımlar atılması önem taşımaktadır. Bunun için öğretmenler teşvik edilip ödüllendirilebilir, ayrıca bir program dahilinde çevre projeleri düzenlenmeleri sağlanabilir. Öğretmenlere proje yazımı, proje hazırlama süreçleri vb. becerileri kazandırmak amacıyla eğitimler verilebilir. 


\section{EXTENDED ABSTRACT}

\section{Investigation of Environmental Knowledge, Attitudes and Behaviors of Primary School Teachers

\author{
Ömer Erbasan - Mehmet Erkol \\ Ministry of National Education- Afyon Kocatepe University
}

Environment is defined as the "setting where a human being or any living creature lives" (Özey, 2009, p.1). The harmony between the living and nonliving elements in this setting is very important for the sustainability of the environment. However, this harmony has started to deteriorate over time because of the human beings, one of the living elements of the system. According to Sever and Yalçınkaya (2012), the phase, where human beings dominated nature, emerged particularly with the industrial revolution, and the change of the balance of power in favor of human beings resulted in rapid and unconscious consumption of the resources in the world and the beginning of environmental problems.

The misunderstanding of human beings related to the environment lies behind the increase of environmental problems in a short time as much as to occupy the agenda of the humanity. There is a misunderstanding that environmental resources are unlimited and the the capacity of the earth to renew itself is sufficient. However, the fallacy of this belief was proven with the rapid depletion of the resources, the insufficiency of the environment to meet the requirements and the increase of the environmental pollution to the extent of endangering human health. It can be argued that this common and false understanding led to the increase in the importance of environmental education. As a matter of fact, dissemination of environmental education is one of the first solution suggestions put forward as a result of many studies, which aim to prevent environmental problems and find ways to return to the healthy state of the environment.

Vaughan, Gack, Solorazano and Ray (2003) defined environmental education as a continuous learning process, in which individuals become aware of their environment as well as gaining knowledge, values, skills and experiences to solve environmental problems for the next generations. One of the 
most important goals of environmental education is to become aware of the impact of our daily life practices on the environment, to avoid behaviors that destroy the environment and to make environmentally friendly choices (Özdemir, 2016, p. 117). According to Kahyaoğlu (2009), environmental problems have gone beyond being problems that could only be solved using technology or laws, and they have become problems that could only be solved through changing individual behaviors. In order to change behaviors, it is very important to change the attitudes and values. The formation of positive attitudes and values towards the environment could be achieved through environmental education.

Considering the importance and impact of education at early ages, the importance of starting environmental education at early ages would be understood better. At this point, it would not be wrong to argue that the environmental knowledge, attitudes and behaviors of the classroom teachers would determine the environmental education of children. Hence, teachers are among the most important determinants of the quality of education. In this sense, the main purpose of our study is to determine the knowledge, attitudes and behaviors of classroom teachers towards environment as individuals who play an important role in the education of children from an early age. In line with this basic purpose, answers to the following sub-problems were sought:

1. What is the level of environmental knowledge of the classroom teachers and would this level differ significantly according to their gender, seniority, residential areas they work in, educational background, membership to non-governmental organizations related to the environment and the availability of previous project experiences on environment?

2. What is the level of the attitudes of classroom teachers towards environmental issues and would this level differ significantly according to their gender, seniority, residential areas they work in, educational background, membership to non-governmental organizations related to the environment and the availability of previous project experiences on environment?

3. What is the level of environmental behaviors of the classroom teachers and would this level differ according to their gender, seniority, residen- 
tial areas they work in, educational background, membership to nongovernmental organizations related to the environment and the availability of previous project experiences on environment?

Survey design was used in the study. The population of the study is composed of classroom teachers employed in public primary schools in Afyonkarahisar province during the 2016-2017 academic year, and the study sample consists of 371 classroom teachers employed in public primary schools in Afyonkarahisar province during the 2016-2017 academic year. In order to collect the data of the study, Environmental Information Test developed by Altınöz (2010), Attitude Scale for Environmental Problems developed by Aksu (2009), and Environmental Behavior Scale developed by Goldman, Yavetz and Pe'er (2006) and adapted by Timur and Yilmaz (2013) were used. The responses of the teachers were analyzed using the SPSS 20 package program. Parametric statistics, which were based on the normal distribution as one of the prerequisites, were performed in the study. Independent groups ttest was performed in order to determine whether the scores of teachers obtained from the data collection tools differed according to gender, educational background, membership to the non-governmental organizations related to the environment, and the availability of previous project experiences on the environment. One-way analysis of variance (ANOVA) test was used to determine whether there was a statistically significant difference with respect to the variables of seniority and residential ares where they work in.

The study concluded that the environmental knowledge and environmental behaviors of classroom teachers were at medium level, and their attitudes towards environmental problems were at a high level. In addition, it was determined that the knowledge, attitude and behavior scores of the teachers did not change according to gender, educational background and membership to non-governmental organizations. When the difference was analyzed according to the seniority variable, while there was no significant difference in terms of knowledge and attitude, the environmental behavior levels of teachers with professional experience of 21 years and above were found to be moderately higher than those of teachers with professional experience between 0-5 years and 6-10 years. However, when the scores were compared according to the residential area, it was concluded that the environmental behavior levels of the teachers employed in the city center were higher than those of the teachers living in the districts, towns or villages. Furthermore, it 
was concluded the availability of previous project experience had a significant effect on attitudes towards environmental problems and environmental behavior scores, but it did not have any significant effects on environmental knowledge.

Based on the findings of our research, the following suggestions could be made:

- In order to increase the environmental knowledge of teachers and enable them to transform their existing attitudes into behavior, they could be provided with practical in-service training, where the information, attitude and behavior dimensions were handled in a balanced way.

- It is important to take steps to ensure that teachers do or participate in projects on the issue. Teachers could be encouraged and rewarded for that, and they could be given the opportunity to organize environmental projects within a certain program.

\section{Kaynakça / References}

Aksu, Y. (2009). Fen ve teknoloji ile sinıföğretmenlerinin çevre sorunlarma yönelik tutumlarmın belirlenmesi:Burdur ili örneği. Yayınlanmamış yüksek lisans tezi). Süleyman Demirel Üniversitesi, Isparta.

Altıöz, N. (2010). Fen bilgisi öğretmen adaylarının çeore okuryazarlık düzeyleri. Yayınlanmamış yüksek lisans tezi. Sakarya Üniversitesi, Sakarya.

Aydemir, M. (2007). The investigation of teachers with respect to knowledge level on environmental concepts. Yayınlanmamış yüksek lisans tezi. Ortadoğu Teknik Üniversitesi, Ankara.

Aydın, N. (2008). Sinıf öğretmeni adaylarını ve öğretmenlerinin çeore eğitimine yönelik öz-yeterlik inançlar üzerine sinı düzeyi, kıdem ve değer yönelimlerinin etkisi. Yayınlanmamış yüksek lisans tezi. Adnan Menderes Üniversitesi, Aydin.

Bilim, İ. (2012). Sürdürülebilir çevre açısından eğitim fakültesi öğrencilerinin çevre okuryazarlk düzeylerinin belirlenmesi. Yayınlanmamış yüksek lisans tezi. Afyon Kocatepe Üniversitesi, Afyonkarahisar.

Bradley, J.C., Waliczek T.M. ve Zajicek J.M. (1999). Relationship between environmental knowledge and environmental attitude of high school students. Jurnal of Environmental Education, 30(3), 17-21. 
Connell, S., Fien, J., Lee, J., Sykes, H. ve Yencken, D. (1999). If it doesn't directly affect you, you don't think about it': A qualitative study of young people's environmental attitudes in two Australian cities. Environmental Education Research, 5(1), 95-113.

Cutter, A. (2002). The Value of Teachers' Knowledge: Environmental Education as a Case Study. 21 Mays, 2017 tarihinde https://files.eric.ed.gov/fulltext/ED466456.pdf adresinden erişilmiştir.

Deniş, H. ve Genç, H. (2007). Çevre bilimi dersi alan ve almayan sınıf öğretmenliği öğrencilerinin çevreye ilişkin tutumları ve çevre bilimi dersindeki başarılarının karşılaştırılması. Mehmet Akif Ersoy Üniversitesi Eğitim Fakültesi Dergisi, 13(2), 20-26.

Erol, G. H. ve Gezer, K. (2006). Prospective of elementary school teachers' attitudes toward environment and environmental problems. International Journal of Environmental and Science Education, 1(1), 65-77.

Erten, S. (2005). Okul öncesi öğretmen adaylarında çevre dostu davranışların araştırılması. Hacettepe Üniversitesi Ĕ̆itim Fakültesi Dergisi, 28(28), 91-100.

Esa, N. (2010). Environmental knowledge, attitude and practices of student teachers. International Research in Geographical and Environmental Education, 19(1), 39-50.

Genç, M. ve Genç, T. (2013). Sınıf öğretmenliği öğrencilerinin çevreye yönelik tutumlarının belirlenmesi. Asian Journal of Instruction, 1(1), 9-19.

Goldman, D., Yavetz, B. ve Pe'er, S. (2006). Environmental literacy in teacher training in Israel: Environmental behavior of new students. The Journal of Environmental Education, 38(1), 3-22.

Güler, E. (2013). Ilköğretim 8. sinıföğrencilerinin çevre okuryazarlğg düzeylerinin belirlenmesi ve öğrencilerin okuryazarlı̆̆ düzeylerinin çeşitli değişkenler açısından incelenmesi. Yayınlanmamış yüksek lisans tezi. Çukurova Üniversitesi, Adana.

Güven, E. (2011). Çevre eğitiminde tahmin-gözlem-açıklama destekli proje tabanlı öğrenme yönteminin farklı değişkenler üzerine etkisi ve yönteme ilişkin öğrenci görüşleri. Yayınlanmamış doktora tezi. Gazi Üniversitesi, Ankara.

Güven, E. (2013). Çevre sorunlarına yönelik tutum ölçeğinin geliştirilmesi ve öğretmen adaylarının tutumlarının belirlenmesi. Gazi University Journal of Gazi Educational Faculty (GUJGEF), 33(2), 411-430. 
Kahyaoğlu, M. (2009). Öğretmen adaylarının fen ve teknoloji dersinde çevresel problemlerin öğretimine yönelik bakış açıları, hazır bulunuşlukları ve öz-yeterliliklerinin belirlenmesi. Mehmet Akif Ersoy Üniversitesi Eğitim Fakültesi Dergisi, 9(17), 28-40.

Karabıçak, M. ve Armağan, R. (2004). Çevre sorunlarının ortaya çıkış süreci, çevre yönetiminin temelleri ve ekonomik etkileri. Süleyman Demirel Üniversitesi İktisadi ve İdari Bilimler Fakültesi Dergisi, 9(2).

Karasar, N. (2015). Bilimsel araşttrma yöntemi-kavramlar, ilkeler, teknikler (28. Baskı). Ankara: Nobel Yayınevi.

Karataş, A. (2013). Çevre bilincinin geliştirilmesinde çevre eğitiminin rolü ve Niğde Üniversitesi Eğitim Fakültesi örneği. (Yayınlanmamış doktora tezi). Ankara Üniversitesi, Ankara.

Karatekin, K. (2011). Sosyal bilgiler öğretmen adaylarını çevre okuryazarlı düzeylerinin belirlenmesi. Yayınlanmamış doktora tezi. Gazi Üniversitesi, Ankara.

Kaya, E., Akıllı, M. ve Sezek, F. (2009). Lise öğrencilerinin çevreye karşı tutumlarının cinsiyet açısından incelenmesi. Mehmet Akif Ersoy Üniversitesi Ĕ̆itim Fakültesi Dergisi, 9(18), 43-54.

Kızıl, M. (2012). Çeore bilimi dersinin fen bilgisi öğretmen adaylarının çeore bilgisi ve çeoreye karsı tutumlarına olan etkisinin incelenmesi. Yayınlanmamış yüksek lisans tezi. Niğde Üniversitesi, Niğde.

Kibert, N. C. (2000). An analysis of the correlations between the attitude, behavior, and knowledge components of environmental literacy in undergraduate university students. Yayınlanmamış doktora tezi. University of Florida, Florida.

Köğce, D., Ünal, S. ve Şahin, B. (2009). The effect of pre-service mathematic teachers' socio-economic status on their ideas and behaviours about environment. Journal of Turkish Science Education, 6(3), 19-37.

Maskan, A. K., Efe, R., Gönen, S. ve Baran, M. (2006). Farklı branşlardaki öğretmen adaylarının çevre sorunlarının nedenleri, eğitimi ve çözümlerine ilişkin görüşlerinin değerlendirilmesi üzerine bir araştırma. Çukurova Üniversitesi Ĕğitim Fakültesi Dergisi, 3(32), 1-12.

McBeth, W. ve Volk, T. L. (2010). The national environmental literacy project: a baseline study of middle grade students in the United States. The Journal of Environmental Education, 41(1), 55-67.

Morgan, G. A., Leech, N. L., Gloeckner, G. W. ve Barrett, K. C. (2004). SPSS for introductory statistics: Use and interpretation. New Jersey: PsychologyPress. 
Morrone, M., Mancl, K. ve Carr, K. (2001). Development of a metric to test group differences in ecological knowledge as one component of environmental literacy. The Journal of Environmental Education, 32(4), 33-42.

Owens, M. A. (2000). The environmental literacy of urban middle school teachers. Yayınlanmamış doktora tezi. Emory University, Atlanta.

Özdemir, O. (2016). Ekolojik okuryazarlk ve çeore eğitimi. Ankara: Pegem Akademi. Özey, R. (2009). Çevre sorunları. Aktif Yayınevi.

Polat, S. (2012). Öğretmen adaylarının (sosyal bilgiler, fen bilgisi, ilköğretim din kültürü ve ahlak bilgisi, türkçe) çeore sorunlarına yönelik tutumları. Yayınlanmamış yüksek lisans tezi. Erciyes Üniversitesi, Kayseri.

Schaefer, G. (1980). Environmental education: A new word or a new philosophy of teaching? E. T. S. Bakshi ve Z. Naveh, (Ed.), Environmental education principles, methods, and applications, New York and London: Plenum Press.

Sever, R. ve Yalçınkaya, E. (2012). Examining the environmental attitudes of preservice teachers on primary school teaching. Marmara Geographical Review, 26, 1-15.

Sipahi, B., Yurtkoru, E. S. ve Çinko, M. (2008). Sosyal bilimlerde SPSS'le veri analizi. İstanbul: Beta Yayınları.

Şahin, M. (2015). Ortaokul öğrencilerinin çevre okuryazarluğı düzeylerinin incelenmesi. Yayınlanmamış yüksek lisans tezi. Aksaray Üniversitesi, Aksaray.

Şerenli, E. (2010). Geleceğin çevre eğitimcilerinin çevre okuryazarlk bileşenlerine sahip olma düzeylerinin belirlenmesi: Muğla Üniversitesi örneği. Yayınlanmamış yüksek lisans tezi. Muğla Üniversitesi, Muğla.

Teksöz, G., Şahin, E. ve Ertepinar, H. (2010). Çevre okuryazarlığı, öğretmen adayları ve sürdürülebilir bir gelecek. Hacettepe Üniversitesi Eğitim Fakültesi Dergisi, 39(39), 307-320.

Timur, S. (2011). Fen bilgisi öğretmen adaylarmın çevre okuryazarlık düzeylerinin belirlenmesi. Yayınlanmamış yüksek lisans tezi. Gazi Üniversitesi, Ankara.

Timur, S. ve Yılmaz, M. (2013). Çevre davranış ölçeğinin Türkçe'ye uyarlanması. Gazi Üniversitesi Gazi Eğitim Fakültesi Dergisi, 33(2), 317-333.

Tungaç, A. S. (2015). Fen bilgisi öğretmenlerinin okul dışı (doğa deneyimine bağlı) çevre eğitimine yönelik özyeterlik algllarl, çeore bilgileri ve çevresel tutumlarmın incelenmesi: Mersin ili örneğgi. Yayınlanmamış yüksek lisans tezi. Mersin Üniversitesi, Mersin.

Uzun, N. (2007). Ortaöğretim öğrencilerinin çevreye yönelik bilgi ve tutumlar üzerine bir çalı̧ma. Yayınlanmamış doktora tezi. Hacettepe Üniversitesi, Ankara. 
Ürey, M. ve Şahin, B. (2010). Akademik personelin çevre sorunları ve çevre eğitimine yönelik duygu, düşünce ve davranışlarının değerlendirilmesi. $\mathrm{Cu}$ kurova University Faculty of Education Journal, 38(3), 134-149.

Vaughan, C., Gack, J., Solorazano, H. ve Ray, R. (2003). The effect of environmental education on schoolchildren, their parents, and community members: A study of intergenerational and intercommunity learning. The Journal of Environmental Education, 34(3), 12-21.

Yavuz, S. (2006). Proje tabanl ö̆grenme modelinin kimya eğitimi öğrencilerinin çevre bilgisi ile çeoreye karşı tutumlarma olan etkisinin değerlendirilmesi. Yayınlanmamış doktora tezi. Hacettepe Üniversitesi, Ankara.

Yıldız, K., Sipahioğlu, Ş. ve Yılmaz, M. (2000). Çevre bilimi. Ankara: Gündüz Eğitim ve Yayıncilik.

\section{Kaynakça Bilgisi / Citation Information}

Erbasan, Ö. ve Erkol, M. (2020). Sınıf öğretmenlerinin çevreye yönelik bilgi, tutum ve davranış düzeylerinin incelenmesi. OPUSUluslararası Toplum Araştırmaları Dergisi, 15(24), 2443-2471. DOI: 10.26466/opus. 619973 